Sains Malaysiana 50(9)(2021): 2537-2548

http://doi.org/10.17576/jsm-2021-5009-04

\title{
Antifungal Effects of Cold Plasma, Coupled with Modified Atmosphere Packaging on Asparagus during Cold Storage
}

(Kesan Antikulat Plasma Sejuk, Ditambah dengan Pembungkusan Atmosfera Terubah ke atas Asparagus Sewaktu Penyimpanan Sejuk)

\author{
Li-Xia WANG, IN-LEE CHOI \& Ho-Min KANG*
}

\section{ABSTRACT}

Asparagus spear is vulnerable to microbial groups which can cause deterioration and short shelf-life after harvesting. The effects of cold plasma, coupled with modified atmosphere (MA) packaging on microorganism development, and quality changes of green asparagus were investigated. The development of microorganisms was inhibited after sterilisation. After 21 days of storage, cold plasma for $6 \mathrm{~h}(\mathrm{P} 6 \mathrm{~h})$ and hot water combined with cold plasma for $3 \mathrm{~h}$ $(H W+P 3 h)$ treatments obtained the lowest number of aerobic bacteria. Hot water $(H W)$, P6h and HW+P3h treatments showed higher inhibition effect on yeast and mold, and also on E. coli. Visual quality and off-odour of P6h treatment were superior to and inferior to other treatments, respectively. Hot water and cold plasma treatments alone inhibited the firming. Cold plasma $1(P 1 h)$ and $3 h(P 3 h)$ were better in retarding yellowing of asparagus. A difference in electrolyte leakage (EL) between control (43\%) and sterilisation treatments (greater than 60\%) was immediately observed on the sterilisation day. Treatments using HW and P1h decreased the EL after 21 days. The soluble solid content (SSC) decreased based on the initial content, and hot water treatment resulted in higher SSC. Increases in ethylene $\left(\mathrm{C}_{2} \mathrm{H}_{4}\right)$ and carbon dioxide production and decrease in oxygen were observed during the first 3 days. The content of $\mathrm{C}_{2} \mathrm{H}_{4}$ under cold plasma treatments was higher than hot water and control on day 21. These results suggested that cold plasma $6 \mathrm{~h}$ treatment resulted in better sensory quality and less decay and softening for green asparagus.

Keywords: Cold storage; electrolyte leakage; microorganisms; yellowing

\section{ABSTRAK}

Pucuk asparagus yang terdedah kepada kumpulan mikrob boleh menyebabkan kemerosotan dan jangka hayat yang pendek selepas dituai. Kesan plasma sejuk, ditambah dengan pembungkusan atmosfera terubah (MA) ke atas perkembangan mikroorganisma dan perubahan kualiti asparagus hijau telah dikaji. Perkembangan mikroorganisma direncat selepas pensterilan. Selepas penyimpanan selama 21 hari, rawatan plasma sejuk selama 6 jam (P6h) dan air panas digabungkan dengan plasma sejuk selama 3 jam $(H W+P 3 h)$ menghasilkan bilangan bakteria aerobik terendah. Air panas (HW), P6h dan HW+P3h menunjukkan kesan perencatan yang lebih tinggi pada yis dan kulat, serta E. coli. Kualiti visual dan bau yang tidak menyenangkan bagi rawatan P6h masing-masing adalah lebih baik dan lebih teruk berbanding rawatan lain. Rawatan air panas dan plasma sejuk sahaja mampu merencatkan kekerasan. Plasma sejuk 1 (P1h) dan 3 jam (P3h) adalah lebih baik dalam membantutkan penguningan asparagus. Perbezaan rawatan kebocoran elektrolit (EL) antara kawalan (43\%) dan pensterilan (lebih 60\%) jelas diperhatikan pada hari pensterilan. Rawatan menggunakan HW dan P1h menurunkan EL selepas 21 hari. Kandungan pepejal larut (SSC) menurun berdasarkan kandungan awal dan rawatan air panas menghasilkan SSC yang lebih tinggi. Peningkatan pengeluaran etilena $\left(\mathrm{C}_{2} \mathrm{H}_{4}\right)$ dan karbon dioksida serta penurunan oksigen diperhatikan pada 3 hari pertama. Kandungan $\mathrm{C}_{2} \mathrm{H}_{4}$ dalam rawatan plasma sejuk lebih tinggi daripada air panas dan kawalan pada hari 21. Hasil ini menunjukkan bahawa rawatan plasma sejuk selama 6 jam menghasilkan asparagus hijau dengan kualiti sensori yang lebih baik dan kurang layu serta lebih lembut.

Kata kunci: Kebocoran elektrolit; mikroorganisma; penguningan; penyimpanan sejuk 


\section{INTRODUCTION}

Green asparagus (Asparagus officinalis L.) is a vegetable with a high value for export and consumption. The short shelf life of 3 to 5 days at ambient temperature during postharvest has been observed due to a very active metabolically and high perishability for green asparagus (Lipton 1990). The high respiration rate and deterioration caused by the infections of microorganisms are serious issues. During postharvest storage at ambient temperature, loss of water loss and toughness, and yellowing easily occur, and the decreases in the soluble solids content and ascorbic acid, and an increase in acidity have been observed during postharvest storage (Siomos et al. 2000). Microbial growth plays a crucial role in the deterioration of fresh produce quality by reducing the shelf life of the product, which significantly impacts consumers' health due to the presence of toxins. Kadau et al. (2004) showed that this loss of quality is accompanied by deterioration caused by bacteria and different molds.

In previous studies, preparations of green asparagus packed with perforated film, micro-perforated film and modified atmosphere film have been investigated (Yoon et al. 2017). Until recently, thermal sterilisation techniques such as cold storage, surface sterilisation pretreatment with a chlorine solution, hot treatment, chitosan and chemical fungicides have not been applied on horticultural crops to control the growth of microorganisms (Qiu et al. 2014). However, along with concerns about the residues and resulting health problems, there is a universal desire to preserve the quality and increase the shelf life of green asparagus. Among the methods explored for microorganism inhibition, hot water treatment at $48{ }^{\circ} \mathrm{C}$ for $2 \mathrm{~min}$ is effective for eliminating microorganisms and prolonging the shelf-life of green asparagus (Yoon et al. 2018).

Cold plasma technology, as a new sterilisation method for vegetables and fruits developed in recent years, has attracted attention due to its simplicity of operation and lack of residue (Thirumdas et al. 2015; Van Alfen 2014). Cold plasma inactivates the microbes on fruits, vegetables and meats using energetic, reactive gases such as electricity, air, oxygen, nitrogen or helium, with no antimicrobial chemical agents required (Niemira 2012), hence it does not leave toxic residues and is harmless for operators (Dhayal et al. 2006). Plasma treatment can affect the different bacterial cell structures, and the reduction of E.coli by orders of magnitude only requires $30 \mathrm{~s}$ of exposure in a $14.2 \%$ plasma stream (Yu et al. 2006). Cold plasma for surface sterilisation treatment is especially desirable in food industries for inpackage decontamination, as it prevents post-processing contamination (Misra et al. 2011; Sen \& Mutlu 2013).

The probable mechanisms involved in the inactivation of microorganisms are the direct destruction and erosion of the microorganisms by cold plasma (Jiang et al. 2014). In addition, previous studies about the role of cold plasma have been reported for enzyme inactivation (Pankaj et al. 2013), toxin degradation and food packaging (Oh et al. 2016). Although cold plasma sterilisation treatment has been used in many horticultural crops such as apples, strawberries, tomatoes, and cucumbers (Mir et al. 2016; Schlüter et al. 2013), its application in green asparagus has not been studied. To fill this gap, we referred to our previous research using hot water and cold plasma in baby leaf vegetables and green asparagus (Kim et al. 2019; Yoon et al. 2018) and performed this experiment with cold plasma and hot water for green asparagus pretreatment before packaging. The objectives of this study were to explore the effectiveness of cold plasma under different durations in maintaining quality and inhibiting microorganism development during cold storage in green asparagus.

\section{MATERIALS AND METHODS}

Green asparagus (A. officinalis L. cv. 'Welcome') was obtained from a local farm in Yanggu-gun, Gangwon-do, Korea. Healthy and uniform $(1.4 \pm 0.1 \mathrm{~cm}$ in diameter and $24 \pm 1.0 \mathrm{~cm}$ in length) green asparagus spears were selected and stored at $4{ }^{\circ} \mathrm{C}$ for this study. Green asparagus spears were pretreated with $48{ }^{\circ} \mathrm{C}$ hot water for $2 \mathrm{~min}$ (HW), atmospheric cold plasma for $1 \mathrm{~h}, 3 \mathrm{~h}$, and $6 \mathrm{~h}(\mathrm{P} 1 \mathrm{~h}$, P3h, P6h), and a combination of hot water and cold plasma for $3 \mathrm{~h}(\mathrm{HW}+\mathrm{P} 3 \mathrm{~h})$. All green asparagus spears were packed in $10,000 \mathrm{cc} / \mathrm{m}^{2}$. day atm oxygen transmission rate (OTR) modified atmosphere (MA) packages (Dae Ryung Precision Packaging Industry Co., Ltd., Gwangjusi, Korea). The evaluation consisted of the analysis of the gas content $\left(\mathrm{CO}_{2}, \mathrm{O}_{2}\right.$, and $\left.\mathrm{C}_{2} \mathrm{H}_{4}\right)$ in the MA packages, overall quality scores, color, firmness, soluble solids content, electrolyte leakage, and total microbial counts.

Microbiological analysis was performed on green asparagus, immediately after the sterilisation treatments and on the final storage day according to Wang et al. (2019) with some modifications. Approximately $2.0 \mathrm{~g}$ fresh asparagus was mixed with $18 \mathrm{~mL}$ of diluent (sterilised water) using a stomacher (Powermixer, B\&F Korea, Gimpo-si, Korea) set at the highest speed for $3 \mathrm{~min}$. The mixture was then diluted at 1:1000. One milliliter 
dilution was dropped on the $3 \mathrm{M}$ aerobic count Petri film plates and cultivated for $24-72 \mathrm{~h}$. The growth of total aerobic bacteria, yeast and mold, and Escherichia coli can be calculated using the $3 \mathrm{M}$ aerobic count Petri film plates (3M Co., St Paul, MN, USA). The concentration of microorganisms is represented as $\log \mathrm{CFU} / \mathrm{g}$.

Gas samples were taken from the package. The carbon dioxide $\left(\mathrm{CO}_{2}\right)$ and oxygen $\left(\mathrm{O}_{2}\right)$ content in the different treatments were measured with an infrared $\mathrm{CO}_{2} / \mathrm{O}_{2}$ analyser (Model Check Mate 9900, PBIDansensor, Ringsted, Denmark), and the ethylene $\left(\mathrm{C}_{2} \mathrm{H}_{4}\right)$ content was measured using a GC-2010 Shimadzu gas chromatography (GC-2010, Shimadzu Corporation, Japan) (Wang et al. 2019). Changes in the atmosphere composition inside the packages were measured every 5 days during the whole cold storage period (21 days).

Firmness was measured at two locations on each asparagus spear from the tips (from topmost $5 \mathrm{~cm}$ ) and the stems (from lowermost $8 \mathrm{~cm}$ ) was measured using a rheometer (Compac-100, Sun Scientific Co. Led., Japan) with a probe $(\varnothing 3.0 \mathrm{~mm})$ at $1.0 \mathrm{~mm} / \mathrm{sec}$ speed. The color parameters were hue angle, chroma, lightness $L^{*}$, $a^{*}$ and $b^{*}$ of asparagus spears were measured using a color-difference meter (Model CR-400, Konica Minolta Sensing, Inc., Japan). The soluble solids content (SSC) was measured by a pocket refractometer (PAL-1, Atago, Japan) and is indicated as ${ }^{\circ}$ Brix at ambient temperature.

Electrolyte leakage (EL) was used to identify the level of tissue damage following Yoon et al. (2018). Approximately $0.6 \mathrm{~g}$ of fresh asparagus slices were excised from asparagus spears and placed in $25 \mathrm{~mL}$ of 0.4 $\mathrm{M}$ mannitol and incubated for $3 \mathrm{~h}$ at ambient temperature and then immediately measured EL value using an EC meter (Cyberscan PC 300, Eutech instruments, Singapore). Electrolyte leakage was also determined on the same sample after being frozen at $-20{ }^{\circ} \mathrm{C}$ for $24 \mathrm{~h}$ and then thawed twice. EL on the sterilisation 0 day and after 21 days was calculated using the following equation:

$$
\text { Relative electrolyte leakage }(\mathrm{EL})=\frac{\mathrm{EL}_{i}}{\mathrm{EL}_{f}} \times 100 \%
$$

The general acceptability of asparagus spears was assessed by five skilled panelists (from the Postharvest Physiology and Distribution Laboratory), to determine the overall appearance of asparagus, including visual quality and impairment during cold storage and on the final storage day according to the methods of Wang et al.
(2019). Asparagus visual quality was assessed on a scale of 1 to 5 ( $1=$ worst, $2=$ bad, $3=$ good, $4=$ better, $5=$ best $)$, and off-odor was assessed on a scale of 0 to $5(0=$ no off-odor and $5=$ strong off-odor). Asparagus spears with a visual quality score equal to or greater than 3.0 and an off-odor score of less than 3.0 were determined to be suitable for sale.

\section{STATISTICAL ANALYSIS}

Microsoft Excel 2019 and IBM SPSS Statistics (24, IBM Corp., Armonk, NY, USA) were used to determine the statistical characteristics of the data. Heatmap was performed using Rstudio version 4.0.2 (Team 2020). Significant differences were tested with ANOVA (one-way analysis of variance) and Duncan's multiple comparisons test at the $\mathrm{P}<0.05$ level. The standard error of each mean is presented $(n=5)$. All experiments were performed with five independent repetitions.

\section{RESULTS AND DISCUSSION}

\section{SENSORIAL EVALUATION OF GREEN ASPARAGUS}

The color parameters of green asparagus were presented by the heatmap in Figure 1. The heatmaps based on Chroma, Hue angle, $L^{*}, a^{*}, b^{*}$ were performed to visualise the significant difference in the color of green asparagus between sterilisation treatments and control groups after 21 days of storage. The sterilisation treatments significantly affected the change of color parameters of green asparagus. The hue angle on the top (tip) was greener than on the bottom (stem) (Figure 1), likely due to the high content of chlorophyll in the tips of green asparagus (Techavuthiporn \& Boonyaritthongchai 2016). After 21 days of storage, a slight yellow coloration was detected in all the treatments tested, and this yellowish color was stronger on the top asparagus spear portions than on the bottom portions. A significant difference between the sterilisation and control was observed in stems but not in tips. A negative value of $a^{*}$ indicates green, while a positive number indicates red-purple color. According to the attribute characteristics of $a^{*}$ and $b^{*}$, the lower the value of $a^{*}$ and $b^{*}$, the greener the asparagus. Hot water treatment exhibited the lowest $a^{*}$ both in tips and in stems, and then the P1h treatment (Figure 1). Likewise, a similar result was observed in $b^{*}$ value. It was indicated that HW and P1h inhibited the yellowing of green asparagus and there was no significant difference between HW and P1h treatments. Compared to control, long-term 
cold plasma treatments and combined with hot water accelerated the yellowing process. The Chroma indicates the color intensity (Chandra et al. 2019), HW and P1h were higher than other sterilisation treatments (Figure
1). $L^{*}$ referred to the lightness of the spear and ranges from black $=0$ to white $=100$ (An et al. 2006). Low levels of $L^{*}$ indicated high levels of browning. As shown in the heatmap, the stem is easier to browning than the tip during
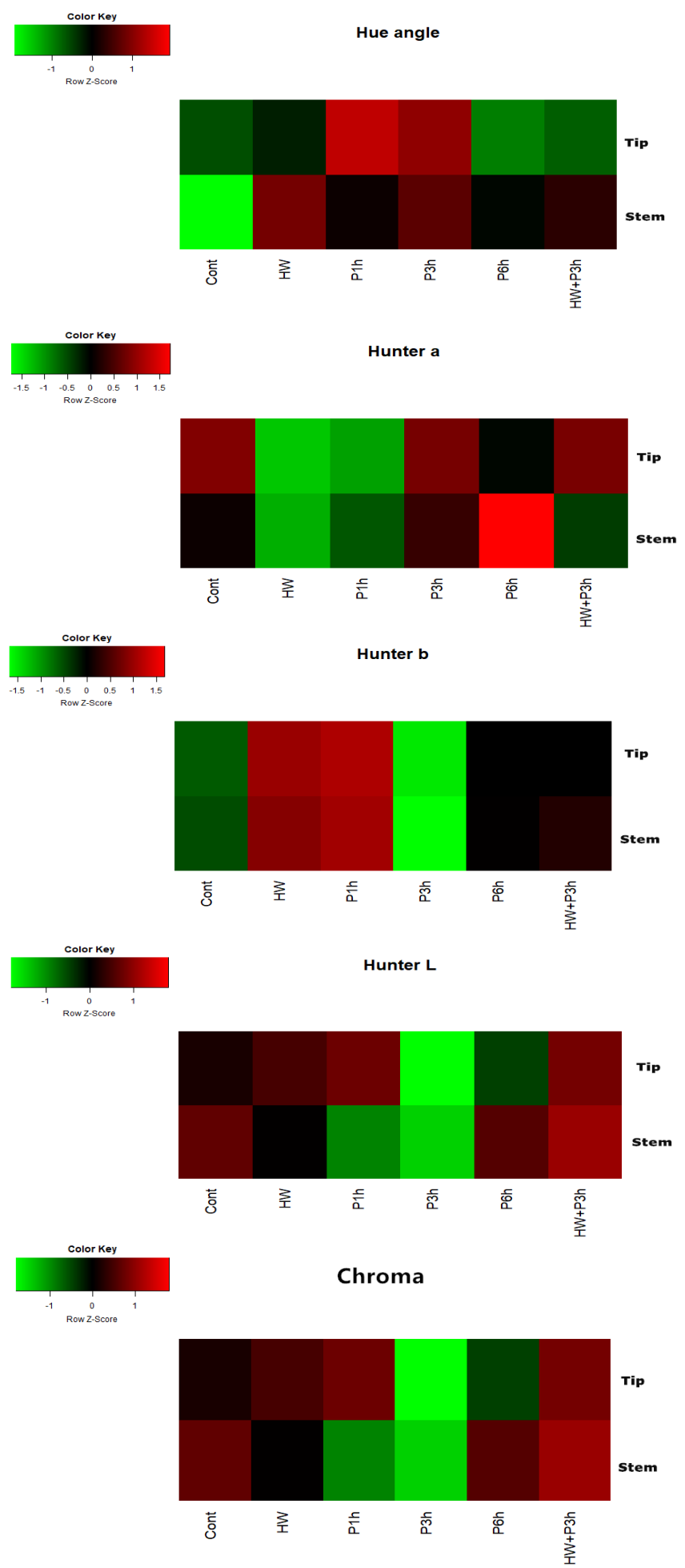

FIGURE 1. Heatmap of color parameters (Chroma, Hue angle, lightness $L^{*}$, redness $a^{*}$, blueness $b^{*}$ ) of green asparagus after 21 days of storage at $4{ }^{\circ} \mathrm{C}$

Cont: control; HW: $48{ }^{\circ} \mathrm{C}$ hot water for $2 \mathrm{~min}$; P1h, P3h, P6h: cold plasma $\left(4^{\circ} \mathrm{C}\right)$ for $1 \mathrm{~h}, 3 \mathrm{~h}, 6 \mathrm{~h}$; $\mathrm{HW}+\mathrm{P} 3 \mathrm{~h}: 48^{\circ} \mathrm{C}$ hot water for $2 \mathrm{~min}$ combined with $4{ }^{\circ} \mathrm{C}$ cold plasma for $3 \mathrm{~h}$ 
storage (Figure 1). Compared to control, $\mathrm{P} 3 \mathrm{~h}$ and $\mathrm{P} 6 \mathrm{~h}$ treatments retarded browning in tips, while $\mathrm{P} 3 \mathrm{~h}$ and $\mathrm{P} 1 \mathrm{~h}$ did that in stems. Previous research on green asparagus showed that $48{ }^{\circ} \mathrm{C}$ hot water for 2 min and 4 min consistently retained a high hue angle and chlorophyll content (Yoon et al. 2018). Regardless of duration, cold plasma treatments performed better at retarding the fade during cold storage than the control group and the combination of hot water and cold plasma for $3 \mathrm{~h}(\mathrm{HW}+\mathrm{P} 3 \mathrm{~h})$. Based on these results, the HW and cold plasma sterilisation individual treatments exhibited beneficial effects on inhibiting the yellowing in green asparagus which likely suppressed the reduction of chlorophyll. Changes in the color parameters of carrots, cucumber and strawberry have been reported by Misra et al. (2014) and Wang et al. (2012) following treatments with cold plasma. Additionally, a relationship between the respiratory rate and chlorophyll degradation was proposed by Cantwell and Reid (1993), a higher respiratory rate caused yellowing of tissue due to the higher ethylene production. Cold plasma treatments retard the respiration rate compared to the untreated strawberry following a period of delay (Misra et al. 2014).

Another important factor that determines the marketability of green asparagus is firmness. The results of current study showed that there was no significant difference in any of the treatments for either the tips or the stems of green asparagus after 21 days of cold storage (Table 1). The control group showed the highest firmness of the tips of green asparagus on the sterilization 0 day, with a significant difference. At the end of the storage period, the texture was firmer than that on the initial day in all the samples. Regardless of the portion of green asparagus, the firmness increased throughout the experimental period. However, this increase was not as large in samples treated with $\mathrm{P} 3 \mathrm{~h}, \mathrm{P} 6 \mathrm{~h}$ and $\mathrm{HW}+\mathrm{P} 3 \mathrm{~h}$ on the top portion and with $\mathrm{P} 1 \mathrm{~h}$, and HW on the base portion. Although the development followed the same patterns, the shear force was greater in tips than in stems on the sterilization 0 day, but after 21 days of cold storage, the results were reversed, with the base firmer than the top (Techavuthiporn \& Boonyaritthongchai 2016). Consequently, in the present work, the increase in firmness was not important in green asparagus pretreatment with cold plasma alone and hot water. It was deduced that under hypobaric conditions $\left(4{ }^{\circ} \mathrm{C}\right)$, the lignification and the cell structure which contribute to the increase of firmness, can be retarded, effectively inhibiting the senescence of asparagus (Li \& Zhang 2006). Likewise, cold plasma treatment did not significantly affect the texture of kiwifruits (Ramazzina et al. 2015), which was caused by enzymatic mediated degradation of hemicellulose, solubilisation of polyuronide and release of galactose from pectic polymers (Rocculi et al. 2005). Cold plasma treatments promoted the inactivation of polyphenoloxidase (PPO) and peroxidase (POD) (Surowsky et al. 2013; Tappi et al. 2014). The effects of cold plasma on the POD and phenylalanine ammonia lyase (PAL) activity levels related to texture in tomato have also been reported (Jiang et al. 2014; Pankaj et al. 2013). Cold plasma might affect the activities of PAL and POD, which are related to the lignification of green asparagus.

TABLE 1. Effect of cold plasma sterilisation treatments on tips and stems firmness and soluble solid content of green asparagus on the sterilisation 0 day and after 21 days of storage at $4{ }^{\circ} \mathrm{C}$

\begin{tabular}{|c|c|c|c|c|c|c|}
\hline \multirow{3}{*}{ Treatments } & \multicolumn{4}{|c|}{ Firmness (N) } & \multicolumn{2}{|c|}{ Soluble solid content $\left({ }^{\circ} \mathrm{Brix}\right)$} \\
\hline & \multicolumn{2}{|c|}{0 day } & \multicolumn{2}{|c|}{21 days } & \multirow{2}{*}{0 day } & \multirow{2}{*}{21 days } \\
\hline & Tip & Stem & Tip & Stem & & \\
\hline Initial & $12.9 \mathrm{ab}$ & $12.6 \mathrm{a}$ & $12.9 \mathrm{a}$ & $12.6 \mathrm{ab}$ & $6.16 \mathrm{a}$ & $6.16 \mathrm{a}$ \\
\hline Control & $13.1 \mathrm{a}$ & $12.1 \mathrm{a}$ & $13.6 \mathrm{a}$ & $14.4 \mathrm{a}$ & $5.73 b c$ & $4.12 \mathrm{~b}$ \\
\hline $\mathrm{HW}$ & $12.2 \mathrm{~d}$ & $12.2 \mathrm{a}$ & $12.8 \mathrm{a}$ & $13.2 \mathrm{ab}$ & $6.08 \mathrm{ab}$ & $4.42 \mathrm{~b}$ \\
\hline $\mathrm{P} 1 \mathrm{~h}$ & $12.2 \mathrm{~d}$ & $12.0 \mathrm{a}$ & $12.9 \mathrm{a}$ & $12.0 \mathrm{~b}$ & $5.30 \mathrm{~d}$ & $4.30 \mathrm{~b}$ \\
\hline $\mathrm{P} 3 \mathrm{~h}$ & $12.9 \mathrm{ab}$ & $12.2 \mathrm{a}$ & $13.3 \mathrm{a}$ & $13.0 \mathrm{ab}$ & $5.40 \mathrm{~cd}$ & $4.18 b$ \\
\hline P6h & $12.6 \mathrm{bc}$ & $12.1 \mathrm{a}$ & $12.9 \mathrm{a}$ & $12.9 \mathrm{ab}$ & $5.45 \mathrm{~cd}$ & $4.12 \mathrm{~b}$ \\
\hline $\mathrm{HW}+\mathrm{P} 3 \mathrm{~h}$ & $12.5 \mathrm{~cd}$ & $12.6 \mathrm{a}$ & $12.9 \mathrm{a}$ & $13.5 \mathrm{ab}$ & $5.13 \mathrm{~d}$ & $4.36 \mathrm{~b}$ \\
\hline
\end{tabular}

HW: $48{ }^{\circ} \mathrm{C}$ hot water for $2 \mathrm{~min}$; P1h, P3h, P6h: cold plasma $\left(4{ }^{\circ} \mathrm{C}\right)$ for $1 \mathrm{~h}, 3 \mathrm{~h}, 6 \mathrm{~h}$; HW+P $3 \mathrm{~h}: 48{ }^{\circ} \mathrm{C}$ hot water for 2 min combined with $4{ }^{\circ} \mathrm{C}$ cold plasma for $3 \mathrm{~h}$. Means $(\mathrm{n}=5)$ followed by different letters are significantly different according to Duncan's multiple range test $(\mathrm{P} \leq 0.05)$ 
The off-odor of asparagus under the P6h treatment was scored as 3 (moderate) and maintained marketability after 21 days of storage (Figure 2). The worst off-odor was observed in the control group, which had the highest score of 3.67. Off-odor is usually due to the production of chemical nature such as methanethiol, dimethyl trisulfide, $\beta$-ionone, ethanol, and acetaldehyde and soft rot caused by microorganisms (Sergio et al. 2018). Sterilisation treatments with both cold plasma alone and the combination delayed the deterioration of the off-odor in MA packages during cold storage, and no significant difference was observed. This result agreed with the development of microorganisms shown in Table 2.

With the prolonging of storage time, the visual quality declined in asparagus spears in all treatments. This reduction was closely associated with visual symptoms of yellowing, decay, water loss and soft rot. Visual quality was insignificantly affected by sterilisation both in individual and combination treatments, except P6h treatment (Figure 2). A visual quality score of $3.25(\geq 3.0)$ indicated the marketability of green asparagus after 21 days of cold storage due to P6h sterilisation treatment. The worst visual quality was obtained in the control group, consistent with the off-odor.

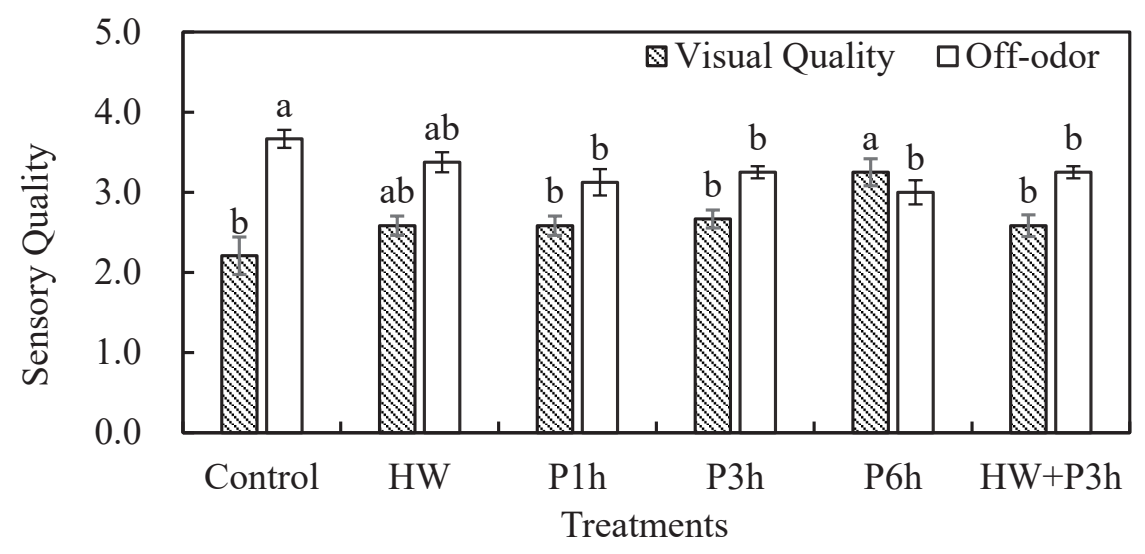

FIGURE 2. Effects of cold plasma sterilisation treatments on off-odor and visual quality after 21 days of storage at $4{ }^{\circ} \mathrm{C}$

HW: $48{ }^{\circ} \mathrm{C}$ hot water for $2 \mathrm{~min}$; P1h, P3h, P6h: cold plasma $\left(4{ }^{\circ} \mathrm{C}\right)$ for $1 \mathrm{~h}, 3 \mathrm{~h}, 6 \mathrm{~h}$; $\mathrm{HW}+\mathrm{P} 3 \mathrm{~h}: 48^{\circ} \mathrm{C}$ hot water for 2 min combined with $4{ }^{\circ} \mathrm{C}$ cold plasma for $3 \mathrm{~h}$

\section{EFFECTS OF COLD PLASMA ON THE BIOCHEMICAL CHARACTERISTICS}

The total soluble solids include sugars, organic acids, soluble pectin, and other constituents. The soluble solids content (SSC) of green asparagus spears in all treatments decreased during overall storage compared to the initially recorded value and on the sterilization 0 day (Table 1). A significant difference was not observed among all the sterilisation treatments after 21 days of cold storage, whereas the soluble solids content was significantly different due to sterilisation treatments on the sterilization 0 day. Likewise, regardless of the cold plasma sterilisation duration, the difference was insignificant. $\mathrm{HW}+\mathrm{P} 3 \mathrm{~h}$ was the highest with a value of 5.13 , corresponding to a loss of approximately $16.7 \%$ of the initial value. The lowest soluble solids content was observed in the HW treatment both on the sterilization 0 day and after 21 days of storage at $4{ }^{\circ} \mathrm{C}$, as the HW treatment inhibited the degradation of soluble solids with a $1.3 \%$ on the sterilization 0 day and with a $28 \%$ of 
soluble solids loss rate after 21 days of storage at $4{ }^{\circ} \mathrm{C}$. These results were consistent with reports by Hazbavi et al. (2015) that a possible reason for changes was possibly that more of the sugar was used in metabolism.

Electrolyte leakage (EL) was significantly affected by sterilisation treatments compared to the control group, on the sterilization 0 day. EL sharply increased after sterilisation treatments, however, did not significantly differ among the sterilisation treatments (Figure 3). In contrast, the effects of the cold plasma treatment duration on EL was shown, with a significant difference among cold plasma treated duration of $1 \mathrm{~h}, 3 \mathrm{~h}$, and $6 \mathrm{~h}$. The EL of all samples decreased again, with the lowest EL after 21 days of storage. $\mathrm{HW}+\mathrm{P} 3 \mathrm{~h}$ caused the maximum disturbance in cell structure and membrane damage with the highest EL value, while HW was the lowest on the sterilization 0 day and after 21 days of cold storage.

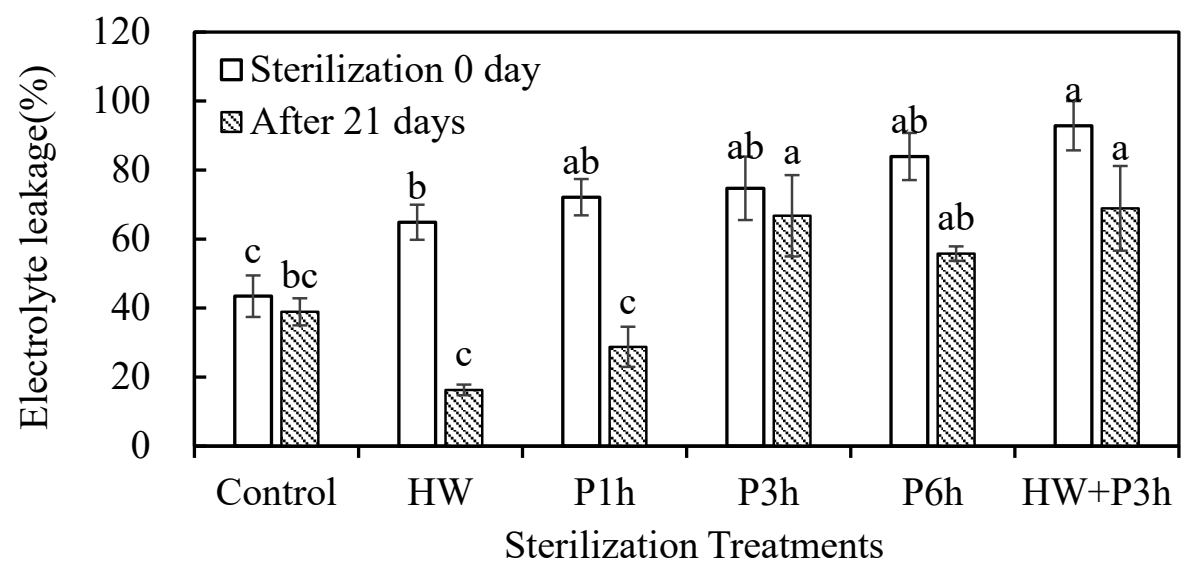

FIGURE 3. Effect of cold plasma sterilisation treatments on the electrolyte leakage (EL) on the sterilisation 0 day and after 21 days of storage $\mathrm{HW}: 48{ }^{\circ} \mathrm{C}$ hot water for $2 \mathrm{~min}$; P1h, P3h, P6h: cold plasma $\left(4{ }^{\circ} \mathrm{C}\right)$ for $1 \mathrm{~h}, 3 \mathrm{~h}, 6 \mathrm{~h}$; $\mathrm{HW}+\mathrm{P} 3 \mathrm{~h}: 48{ }^{\circ} \mathrm{C}$ hot water for 2 min combined with $4{ }^{\circ} \mathrm{C}$ cold plasma for $3 \mathrm{~h}$

\section{EFFECTS ON $\mathrm{CO}_{2}$ AND $\mathrm{O}_{2}$ CONTENT AND ETHYLENE PRODUCTION}

Atmospheric modification rapidly occurred within one day after asparagus spears were packaged with MA film, and an increase in $\mathrm{CO}_{2}$ content and a decrease in $\mathrm{O}_{2}$ content in MA packages were found during the first three days of cold storage (Figure 4). After day 3, the $\mathrm{CO}_{2}$ content decreased due to the decreased respiration rate and then achieved equilibrium (Papadopoulou et al. 2001). The $\mathrm{CO}_{2}$ content in samples subjected to the P6h treatment was slightly lower than that of the other samples, and the content in the control group was higher than that of others. However, the pattern of the decrease of the $\mathrm{O}_{2}$ content did not correspond to that of the increase of $\mathrm{CO}_{2}$. The $\mathrm{O}_{2}$ content in MA packages was slightly higher, and $\mathrm{HW}+\mathrm{P} 3 \mathrm{~h}$ had the lowest $\mathrm{O}_{2}$ content. The greater decrease of the oxygen content with $\mathrm{HW}+\mathrm{P} 3 \mathrm{~h}$ possibly indicated more rapid $\mathrm{O}_{2}$ diffusion into the cell interior of injured tissues, increasing their metabolic activity (Watada et al. 1996).

During the storage period, the $\mathrm{CO}_{2}$ and $\mathrm{O}_{2}$ content remained stable at 1 to $4 \%$ and 18 to $21 \%$, respectively. No prominent difference in the $\mathrm{CO}_{2}$ and $\mathrm{O}_{2}$ content were observed in any package during cold storage in both 
control and sterilisation treated asparagus. The respiration rate of asparagus in packages was related to the content of $\mathrm{CO}_{2}$ and $\mathrm{O}_{2}$, and the rapid atmospheric modification was the result of the high respiration rate of green asparagus in MA packages (Papadopoulou et al. 2001), however, the degree of modification was not greatly influenced by the sterilisation treatment method or duration. In this experiment, the content of $\mathrm{O}_{2}$ never fell below 3\%, under which green asparagus respiration can change to anaerobic (Torres-Penaranda \& Saltveit 1994). The finding indicated that MA packages benefited the preservation of green asparagus by reducing respiration and ethylene production, retarding softening and reducing decay and so forth, and the recommended gas composition in packages for green asparagus was an $\mathrm{O}_{2}$ content similar to air and 5 to $10 \% \mathrm{CO}_{2}$ at $5{ }^{\circ} \mathrm{C}$ (Kader et al. 1989). The $\mathrm{O}_{2}$ content in this research was consistent with this level and the $\mathrm{CO}_{2}$ content was slightly lower than $5 \%$.

The ethylene content in packages was assessed during storage at $4{ }^{\circ} \mathrm{C}$. The ethylene content in all MA packages increased to 6 to $8 \mu \mathrm{L} / \mathrm{L}$ by 3 days of storage under the $\mathrm{P} 1 \mathrm{~h}$ and $\mathrm{P} 3 \mathrm{~h}$ treatments, and by 1 day of storage under the other treatment. Previous research has shown that wound ethylene is induced by cutting at harvest in green asparagus (Papadopoulou et al. 2001). Subsequently, the change in the ethylene content was not
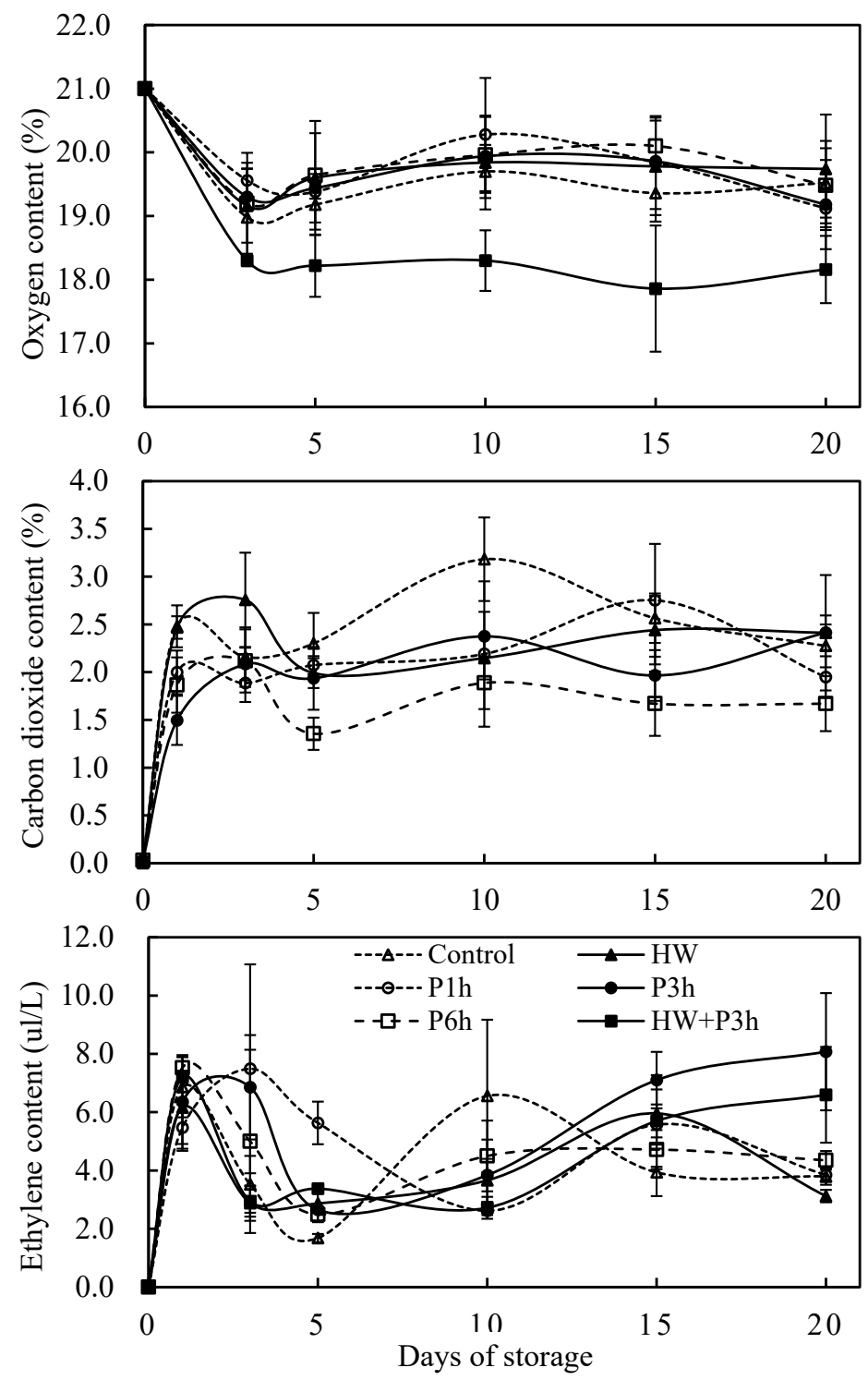

FIGURE 4. Changes in the carbon dioxide $\left(\mathrm{CO}_{2}\right)$, oxygen $\left(\mathrm{O}_{2}\right)$ and ethylene $\left(\mathrm{C}_{2} \mathrm{H}_{4}\right)$ content in packages of green asparagus

HW: $48^{\circ} \mathrm{C}$ hot water for $2 \mathrm{~min}$; P1h, P3h, P6h: cold plasma $\left(4^{\circ} \mathrm{C}\right)$ for $1 \mathrm{~h}, 3 \mathrm{~h}, 6 \mathrm{~h}$; HW+P $3 \mathrm{~h}: 48$

${ }^{\circ} \mathrm{C}$ hot water for 2 min combined with $4{ }^{\circ} \mathrm{C}$ cold plasma for $3 \mathrm{~h}$ 
stable but lower than that on the initial day of storage, 8 $\mu \mathrm{L} / \mathrm{L}$. The control group had a different fluctuation trend than the sterilisation treatment groups after 5 days of storage. After 21 days of cold storage, the HW+P3h and $\mathrm{P} 3 \mathrm{~h}$ treatments exhibited the higher ethylene content which was close to the highest content in storage duration of nearly $8 \mu \mathrm{L} / \mathrm{L}$. It has been confirmed that ethylene is a general response of plant tissues to injuries through the activation of ACC synthase and ACC oxidase (Kato et al. 2000). With the prolonged storage time, the tissue damage becomes serious and induces ethylene production.

\section{EFFECTS ON THE GROWTH OF MICROORGANISMS}

The results of microorganisms showed that the initial microbial loads on untreated control samples were $4.10 \log \mathrm{CFU} / \mathrm{g}$ total aerobic bacteria, $1.43 \mathrm{log} \mathrm{CFU} / \mathrm{g}$ yeast and mold, and $1.49 \log \mathrm{CFU} / \mathrm{g}$ E. coli (Table 2). Compared to the control samples, the development of microorganism populations was inhibited by all the sterilisation treatments on sterilisation 0 day and significant differences among all sterilisation treatments effectiveness were observed in total aerobic bacteria, but not in yeast and mold. Based on these data, regardless of the sterilisation duration, cold plasma alone and the combination of hot water and cold plasma inhibited the development of $E$. coli on the sterilization 0 day, despite insignificant statistical differences in the treatment efficiency with $0 \log \mathrm{CFU} / \mathrm{g}$. The inactivation of $E$. coli resulted from the destruction of the cytoplasmic membrane and the outer membrane under plasma exposure (Takehiko et al. 2006). This result implied that E. coli was probably more susceptible to cold plasma treatment than other bacteria (Misra et al. 2014). In contrast, following 21 days of cold storage, the number of microorganisms were significantly increased both in the control group and the sterilisation groups. After 21 days of cold storage, the P6h treatment resulted in the greatest reduction in total aerobic bacteria of $3.73 \mathrm{log} \mathrm{CFU} / \mathrm{g}$ followed by the $\mathrm{HW}+\mathrm{P} 3 \mathrm{~h}$ treatment of $5.19 \log \mathrm{CFU} / \mathrm{g}$, compared to the control group. Regarding the growth of yeast and mold, the greatest effect against these was the $\mathrm{HW}+\mathrm{P} 3 \mathrm{~h}$ treatment, with the lowest number of $2.10 \log \mathrm{CFU} / \mathrm{g}$, followed by the HW treatment of $2.52 \log \mathrm{CFU} / \mathrm{g}$. The development of E. coli was most inhibited by $\mathrm{P} 6 \mathrm{~h}$ sterilisation treatment compared to the other treatments after 21 days of cold storage. The lowest number of $E$. coli was $3.00 \mathrm{log}$ CFU/g in the P6h treatment. In evaluating the influence of cold plasma and hot water sterilisation treatments on the growth of microorganism populations, the P6h treatment exhibited significantly greater reductions and inhibition after a long period of storage, while $\mathrm{HW}+\mathrm{P} 3 \mathrm{~h}$ showed stronger inhibition on the sterilization 0 day. The higher sterilisation effect of $\mathrm{HW}+\mathrm{P} 3 \mathrm{~h}$ was probably due to heat induction (Francesco et al. 2018).

TABLE 2. Effect of cold plasma on growth inhibition of microorganism (total aerobic bacteria, yeast and mold, E. coli) on the sterilisation 0 day and after 21 days of storage at $4{ }^{\circ} \mathrm{C}$

\begin{tabular}{|c|c|c|c|c|c|c|}
\hline \multirow{3}{*}{ Treatments } & \multicolumn{6}{|c|}{ Number of microorganisms $(\log \mathrm{CFU} / \mathrm{g})$} \\
\hline & \multicolumn{2}{|c|}{ Total aerobic bacteria } & \multicolumn{2}{|c|}{ Yeast and mold } & \multicolumn{2}{|c|}{ E. coli } \\
\hline & 0 day & 21 days & 0 day & 21 days & 0 day & 21 days \\
\hline Control & $4.10 \mathrm{a}$ & $5.57 \mathrm{~b}$ & $1.43 \mathrm{a}$ & $3.10 \mathrm{ab}$ & $1.49 \mathrm{~b}$ & $4.90 \mathrm{c}$ \\
\hline HW & $3.90 \mathrm{~b}$ & $5.81 \mathrm{a}$ & $0.00 \mathrm{a}$ & $2.52 \mathrm{~d}$ & $2.48 \mathrm{a}$ & $3.85 \mathrm{e}$ \\
\hline P1h & $3.44 \mathrm{~d}$ & $5.86 \mathrm{a}$ & $0.67 \mathrm{a}$ & $3.32 \mathrm{a}$ & $0.00 \mathrm{c}$ & $5.10 \mathrm{~b}$ \\
\hline $\mathrm{P} 3 \mathrm{~h}$ & $3.25 \mathrm{e}$ & $5.93 \mathrm{a}$ & $0.00 \mathrm{a}$ & $2.62 \mathrm{~cd}$ & $0.00 \mathrm{c}$ & $5.89 \mathrm{a}$ \\
\hline P6h & $3.69 \mathrm{c}$ & $3.73 d$ & $0.67 \mathrm{a}$ & $2.86 b c$ & $0.00 \mathrm{c}$ & $3.00 \mathrm{f}$ \\
\hline $\mathrm{HW}+\mathrm{P} 3 \mathrm{~h}$ & $3.86 \mathrm{~b}$ & $5.19 \mathrm{c}$ & $0.67 \mathrm{a}$ & $2.10 \mathrm{e}$ & $0.00 \mathrm{c}$ & $4.25 \mathrm{~d}$ \\
\hline
\end{tabular}

HW: $48{ }^{\circ} \mathrm{C}$ hot water for $2 \mathrm{~min}$; P1h, P3h, P6h: cold plasma $\left(4{ }^{\circ} \mathrm{C}\right)$ for $1 \mathrm{~h}, 3 \mathrm{~h}, 6 \mathrm{~h} ; \mathrm{HW}+\mathrm{P} 3 \mathrm{~h}: 48{ }^{\circ} \mathrm{C}$ hot water for 2 min combined with $4{ }^{\circ} \mathrm{C}$ cold plasma for $3 \mathrm{~h}$. Mean $(\mathrm{n}=5)$ followed by different letters are significantly different according to Duncan's multiple range test $(\mathrm{P} \leq 0.05)$ 


\section{CONCLUSION}

Green asparagus has a short post-harvest shelf-life due to the contamination with microorganisms and its high metabolic activity. The initial microbial levels on the surface can influence the inactivation rate of microbes. Therefore, the application of sterilisation technologies to improve the shelf life of asparagus by inhibiting the growth of microbial groups and maintaining its sensory qualities is essential. The efficacy of hot water pretreatment (HW) on green asparagus before cold storage has been used. The cold plasma pretreatments alone with different durations and the combination with hot water were investigated. All the treatments inhibited the development of microorganisms, and there was no negative effect on the quality of asparagus. However, cold plasma alone with less than $6 \mathrm{~h}$ of treatment and the hot water treatment did not show an obvious sterilisation efficiency. The $\mathrm{HW}+\mathrm{P} 3 \mathrm{~h}$ and $\mathrm{P} 6 \mathrm{~h}$ pretreatments can be considered beneficial in light of their microbial reductions, with good retention of quality attributes. The present findings might have important implications for preserving the traits, and prolonging the shelf-life of green asparagus and inactivating microbes by using cold plasma after harvested.

\section{ACKNOWLEDGEMENTS}

This research was supported by Korea Institute of Planning and Evaluation for Technology in Food, Agriculture and Forestry (IPET) through Agri-Food Export Business Model Development Program, funding from the Ministry of Agriculture, Food and Rural Affairs (319088033SB010), and Basic Science Research Program through the National Research Foundation of Korea (NRF) funded by the Ministry of Education (NRF2021R1A6A1A03044242). Li-Xia Wang and In-Lee Choi contributed equally to this work.

\section{REFERENCES}

An, J.S., Zhang, M., Lu, Q.R. \& Zhang, Z.G. 2006. Effect of a prestorage treatment with 6-benzylaminopurine and modified atmosphere packaging storage on the respiration and quality of green asparagus spears. Journal of Food Engineering 77(4): 951-957.

Cantwell, M.I. \& Reid, M.S. 1993. Postharvest physiology and handling of fresh culinary herbs. Journal of Herbs, Spices \& Medicinal Plants 1(3): 93-127.

Chandra, D., Lee, J.S., Hong, Y.P., Park, M.H., Choi, A.J. \& Kim, J.G. 2019. Short-term application of CO2 gas: Effects on physicochemical, microbial, and sensory qualities of
"Charlotte" strawberry during storage. Journal of Food Safety 39(2): e12597.

Dhayal, M., Lee, S.Y. \& Park, S.U. 2006. Using lowpressure plasma for Carthamus tinctorium L. seed surface modification. Vacuum 80(5): 499-506.

Francesco, A.D., Mari, M. \& Roberti, R. 2018. Defense response against postharvest pathogens in hot water treated apples. Scientia Horticulturae 227: 181-186.

Hazbavi, I., Khoshtaghaza, M.H., Mostaan, A. \& Banakar, A. 2015. Effect of postharvest hot-water and heat treatment on quality of date palm (cv. Stamaran). Journal of the Saudi Society of Agricultural Sciences 14(2): 153-159.

Jiang, J.F., Lu, Y.F., Li, J.G., Li, L., He, X., Shao, H.L. \& Dong, Y.H. 2014. Effect of seed treatment by cold plasma on the resistance of tomato to Ralstonia solanacearum (Bacterial Wilt). PloS ONE 9(5): e97753.

Kadau, R., Huyskens-Keil, S., Gosmann, M. \& Büttner, C. 2004. Effect of film packaging on phytopathological and physiological processes of fresh-cut white asparagus (Asparagus officinalis L.) during storage. Proceedings of the 5th International Postharvest Symposium 682: 18651870.

Kader, A.A., Zagory, D., Kerbel, E.L. \& Wang, C.Y. 1989. Modified atmosphere packaging of fruits and vegetables. Critical Reviews in Food Science and Nutrition 28(1): 1-30.

Kato, M., Hayakawa, Y., Hyodo, H., Ikoma, Y. \& Yano, M. 2000. Wound-induced ethylene synthesis and expression and formation of 1-aminocyclopropane-1-carboxylate (ACC) synthase, ACC oxidase, phenylalanine ammonia-lyase, and peroxidase in wounded mesocarp tissue of Cucurbita maxima. Plant Cell Physiology 41(4): 440-447.

Kim, J.Y., Han, S.J., Wang, L.X., Lee, J.H., Choi, I.L. \& Kang, H.M. 2019. Effects of chlorine water and plasma gas treatments on the quality and microbial control of Latuca indica L. baby leaf vegetable during MA storage. Protected Horticulture and Plant Factory 28(3): 197-203.

Li, W.X. \& Zhang, M. 2006. Effect of three-stage hypobaric storage on cell wall components, texture and cell structure of green asparagus. Journal of Food Engineering 77(1): 112-118.

Lipton, W.J. 1990. Postharvest biology of fresh asparagus. Horticultural Reviews 12: 69-155.

Mir, S.A., Shah, M.A. \& Mir, M.M. 2016. Understanding the role of plasma technology in food industry. Food and Bioprocess Technology 9(5): 734-750.

Misra, N.N., Moiseev, T., Patil, S., Pankaj, S.K., Bourke, P., Mosnier, J.P., Keener, K.M. \& Cullen, P.J. 2014. Cold plasma in modified atmospheres for post-harvest treatment of strawberries. Food and Bioprocess Technology 7(10): 3045-3054.

Misra, N.N., Tiwari, B.K., Raghavarao, K.S.M.S. \& Cullen, P.J. 2011. Nonthermal plasma inactivation of food-borne pathogens. Food Engineering Reviews 3(3-4): 159-170. 
Niemira, B.A. 2012. Cold plasma decontamination of foods. Annual Review of Food Science and Technology 3(1): 125142.

Oh, Y.A., Roh, S.H. \& Min, S.C. 2016. Cold plasma treatments for improvement of the applicability of defatted soybean meal-based edible film in food packaging. Food Hydrocolloids 58: 150-159.

Pankaj, S.K., Misra, N.N. \& Cullen, P.J. 2013. Kinetics of tomato peroxidase inactivation by atmospheric pressure cold plasma based on dielectric barrier discharge. Innovative Food Science \& Emerging Technologies 19: 153-157.

Papadopoulou, P., Siomos, A. \& Dogras, C. 2001. Metabolism of etiolated and green asparagus before and after harvest. The Journal of Horticultural Science and Biotechnology 76(4): 497-500.

Qiu, M., Wu, C., Ren, G.R., Liang, X.L., Wang, X.Y. \& Huang, J.Y. 2014. Effect of chitosan and its derivatives as antifungal and preservative agents on postharvest green asparagus. Food Chemistry 155: 105-111.

Ramazzina, I., Berardinelli, A., Rizzi, F., Tappi, S., Ragni, L., Sacchetti, G. \& Rocculi, P. 2015. Effect of cold plasma treatment on physico-chemical parameters and antioxidant activity of minimally processed kiwifruit. Postharvest Biology and Technology 107: 55-65.

Rocculi, P., Romani, S. \& Dalla, R.M. 2005. Effect of MAP with argon and nitrous oxide on quality maintenance of minimally processed kiwifruit. Postharvest Biology and Technology 35(3): 319-328.

Schlüter, O., Ehlbeck, J., Hertel, C., Habermeyer, M., Roth, A., Engel, K.H., Holzhauser, T., Knorr, D. \& Eisenbrand, G. 2013. Opinion on the use of plasma processes for treatment of foods. Molecular Nutrition \& Food Research 57(5): 920-927.

Sen, Y. \& Mutlu, M. 2013. Sterilisation of food contacting surfaces via non-thermal plasma treatment: A model study with Escherichia coli-contaminated stainless steel and polyethylene surfaces. Food and Bioprocess Technology 6(12): 3295-3304.

Sergio, L., Cantore, V., Spremulli, L., Pinto, L., Baruzzi, F., Di Venere, D. \& Boari, F. 2018. Effect of cooking and packaging conditions on quality of semi-dried green asparagus during cold storage. Lwt-Food Science and Technology 89: 712-718.

Siomos, A.S., Sfakiotakis, E.M. \& Dogras, C.C. 2000. Modified atmosphere packaging of white asparagus spears: Composition, color and textural quality responses to temperature and light. Scientia Horticulturae 84(1-2): $1-13$.

Surowsky, B., Fischer, A., Schlueter, O. \& Knorr, D. 2013. Cold plasma effects on enzyme activity in a model food system. Innovative Food Science \& Emerging Technologies 19: 146-152.
Takehiko, S., Takashi, M., Akiko, D., Shiroh, O., Takuya, U. \& Tatsuyuki, N. 2006. Sterilisation mechanism for Escherichia coli by plasma flow at atmospheric pressure. Applied Physics Letters 89(7): 073902.

Tappi, S., Berardinelli, A., Ragni, L., Dalla Rosa, M., Guarnieri, A. \& Rocculi, P. 2014. Atmospheric gas plasma treatment of fresh-cut apples. Innovative Food Science \& Emerging Technologies 21: 114-122.

Techavuthiporn, C. \& Boonyaritthongchai, P. 2016. Effect of prestorage short-term anoxia treatment and modified atmosphere packaging on the physical and chemical changes of green asparagus. Postharvest Biology and Technology 117: 64-70.

Thirumdas, R., Sarangapani, C. \& Annapure, U.S. 2015. Cold plasma: A novel non-thermal technology for food processing. Food Biophysics 10(1): 1-11.

Torres-Penaranda, A.V. \& Saltveit, M.E. 1994. Effects of brief anaerobic exposures on carbon dioxide production and quality of harvested asparagus. Journal of the American Society for Horticultural Science 119(3): 551-555.

Van Alfen, N.K. 2014. Encyclopedia of Agriculture and Food Systems. 2nd ed. New York: Elsevier.

Wang, R.X., Nian, W.F., Wu, H.Y., Feng, H.Q., Zhang, K., Zhang, J., Zhu, W.D., Becker, K.H. \& Fang, J. 2012. Atmosphericpressure cold plasma treatment of contaminated fresh fruit and vegetable slices: Inactivation and physicochemical properties evaluation. The European Physical Journal D 66(10): 276.

Wang, L.X., Choi, I.L., Lee, J.H. \& Kang, H.M. 2019. The effect of high $\mathrm{CO}_{2}$ treatment and MA packaging on asparagus quality and shelf life during cold storage. Journal of Agricultural, Life and Environmental Sciences 31(2): 41-49.

Watada, A.E., Ko, N.P. \& Minott, D.A. 1996. Factors affecting quality of fresh-cut horticultural products. Postharvest Biology and Technology 9(2): 115-125.

Yoon, H.S., Choi, I.L., Heo, J.Y., Kim, J.Y., Han, S.J. \& Kang, H.M. 2018. Influence of hot water immersion and MAP pretreatments on sterilisation and asparagus spear qualities during cold storage. Horticultural Science and Technology 36(5): 756-765.

Yoon, H.S., Choi, I.L. \& Kang, H.M. 2017. Different oxygen transmission rate packing films during modified atmosphere storage: Effects on asparagus spear quality. Horticultural Science and Technology 35(3): 314-322.

Yu, Q.S., Huang, C., Hsieh, F.H., Huff, H. \& Duan, Y.X. 2006. Sterilisation effects of atmospheric cold plasma brush. Applied Physics Letters 88(1): 013903.

Li-Xia Wang

Institute of Vegetables

Shandong Academy of Agricultural Sciences

Jinan city 250100, Shandong Province

China 
Li-Xia Wang, In-Lee Choi \& Ho-Min Kang*

Division of Horticulture and Systems Engineering

Program of Horticulture

Kangwon National University

Chuncheon 24341

Republic of Korea

In-Lee Choi

Agricultural and Life Science Research Institute

Kangwon National University

Chuncheon 24341

Republic of Korea
Ho-Min Kang*

Kangwon National University

Interdisciplinary Program in Smart Agriculture

Chuncheon 24341

Republic of Korea

*Corresponding author; email: homimkang@kangwon.ac.kr

Received: 30 March 2020

Accepted: 28 January 2021 